DOI: 10.20472/IAC.2017.030.026

\author{
JANA ŠTOFKOVÁ \\ Žilinská univerzita v Žiline, Slovak Republic \\ STANISLAV ŠTOFKO \\ Žilinská univerzita v Žiline, Slovak Republic \\ KATARÍNA GAŠOVÁ \\ Žilinská univerzita v Žiline, Slovak Republic
}

\title{
SOME ASPECTS OF INDUSTRIAL POLICY IN SLOVAKIA
}

\begin{abstract}
:
In contrast to the fiscal and financial policy there is no precise, universally accepted definition of industrial policy. Industry influences crucially the development of each region, largely contributes to the development of the economy. The financial and economic crisis over the last decade affected the industry in Slovakia and other EU countries. Due to the fact that the Slovak Republic is a small open economy for purposes of comparison were chosen countries with small economies and a different competitiveness. Slovak Republic has the most developed automobile industry. It is necessary to ensure the competitiveness bear in mind the increasing employment, improving quality of life and reducing environmental pollution. Several results of a survey are presented, also some measures that could improve competitiveness as well as sustainable development.
\end{abstract}

\section{Keywords:}

Industrial policy, competitiveness, automobile industry, industrial structure, sustainable development

JEL Classification: 025 


\section{Introduction}

Industrial policy in a wider sense constitute general measures for the further development of the internal market policy, foreign trade and the various contracts and agreements relating to specific industry sectors, social and regional policy, competition policy, aimed at promoting science and research, constantly strengthening and enhancing cooperation between companies. The broad concept of industrial policy should unite offering economic, social and environmental objectives. Concept should focus for example on the sustainable use of resources (materials and energy) and environmental protection. It is also clear relationship between sustainability and competitiveness.

\section{Industrial policy}

Industrial policy as a form of economic policy has been discussed in different periods. This was due to the fact that in contrast to fiscal or financial policies, there is no universally accepted definition of industrial policy. Its understanding is different at different levels and in different countries. One of the definitions of industrial policy states "for the industrial policy, we can select all actions of the government and its institutions, which are aimed at achieving changes in the industry and by means of incentives result in the production of certain industrial products, or have an impact on the issue of entry or exit from a particular industrial sector. If we wanted to simply industrial policy we can say that it is a set of public sector activities that affect the performance of the processing sector or the service sector." (Sipko, 2004)

The term industrial policy can also be understood as "a set of actions of government bodies that are focused on the process of structural adjustment, which aims to gain comparative advantages of some economy in the global economic market." (Lipkova, 2011) Every form of economic policy effects on the industry, and thus becomes in a sense, a part of industrial policy. (Nemcova, 2013)

Ensuring the framework conditions beneficial to industrial competitiveness is industrial policy objectives. Industrial policy is specifically focused on:

- speeding up the adjustment of industry to structural changes,

- support an environment suitable to the creation and development of enterprises, especially small and medium-sized enterprises,

- support a cooperation between enterprises,

- better exploitation of the industrial potential of innovation, research and technological development. (EP, 2016)

The European Union has set objectives in industry and innovation by 2020 as follows:

- strengthen European industrial base enhance its competitiveness,

- support the transition towards a low carbon economy,

- support for innovation as a means to generate new sources of growth and meet social needs, 
- support the creation and growth of SMEs and the promotion of entrepreneurial culture,

- ensure a function of open internal market for goods. (EC, 2016)

Among the instruments of industrial policy can be considered subsidies, tax breaks, investment in human capital, investment in technology, government guarantees, licenses and patents, government contracts, soft loans, export promotion etc. (Vidova, 2015)

\section{Industrial policy and competitiveness}

Michael Porter (Porter, 1990) has brought in a reflection on the competitiveness concept of competitive advantage. Many studies, however, apply only national economic system tools, as well as marketing theory. The conclusions of these can be used mainly in business management and development of indicators at the sector level. (Nemcova, 1998; Daneshjo, 2016)

At present, the more urgent becomes the question of coordinating the demands of increasing industrial competitiveness and the principles of sustainable development into industrial policy so as to contribute to the elimination of the consequences of the crisis. Necessary in this context is to determine the long-term industrial policy objectives, changes in the industry and its business environment, which are crucial for starting economic growth and secure jobs as well as actions leading to the successful transformation of the industry.

The fundamental principle of industrial policy is to create a favorable environment to increase its competitiveness. Among the important factors of competitiveness we can include more efficient innovation, obtaining a highly skilled workforce, integration of research results to the market etc. (EC, 2014)

Factors increasing competitiveness can assign elements such as quality, reaction speed, user-orientation, image production, sales service and others. (Nemcova, 2013)

\section{Structure of industry in Slovakia}

Slovakia is a small open economy, well integrated into the global economy and the common market. Among the countries of the European Union, Slovakia has one of the fastest growing economies. On basis of the unit labour costs in the Slovak industry is the most competitive group of new Member States. On export takes a significant share cars and car parts, consumer electronics, machinery and metal products. Slovakia has a competitive advantage in foreign direct investment and technology transfer, production processes etc. Good external competitiveness and lower imports bring the current account into balance, and production of some industries has reached record levels.

For example, relatively high electricity prices, in particular for SMEs, continue to hamper the competitiveness of Slovak industry. Industry continues to play an important role in the economy. The main export items are cars and car parts, consumer electronics, machinery and metal. The share of high-tech products in total 
exports increased slightly. In comparison with similar economies in the EU, the domestic value added content of exports is relatively low, to maintain export capacity. (CzechTrade, 2016)

Figure 1. The sectoral structure of the manufacturing industry Slovakia

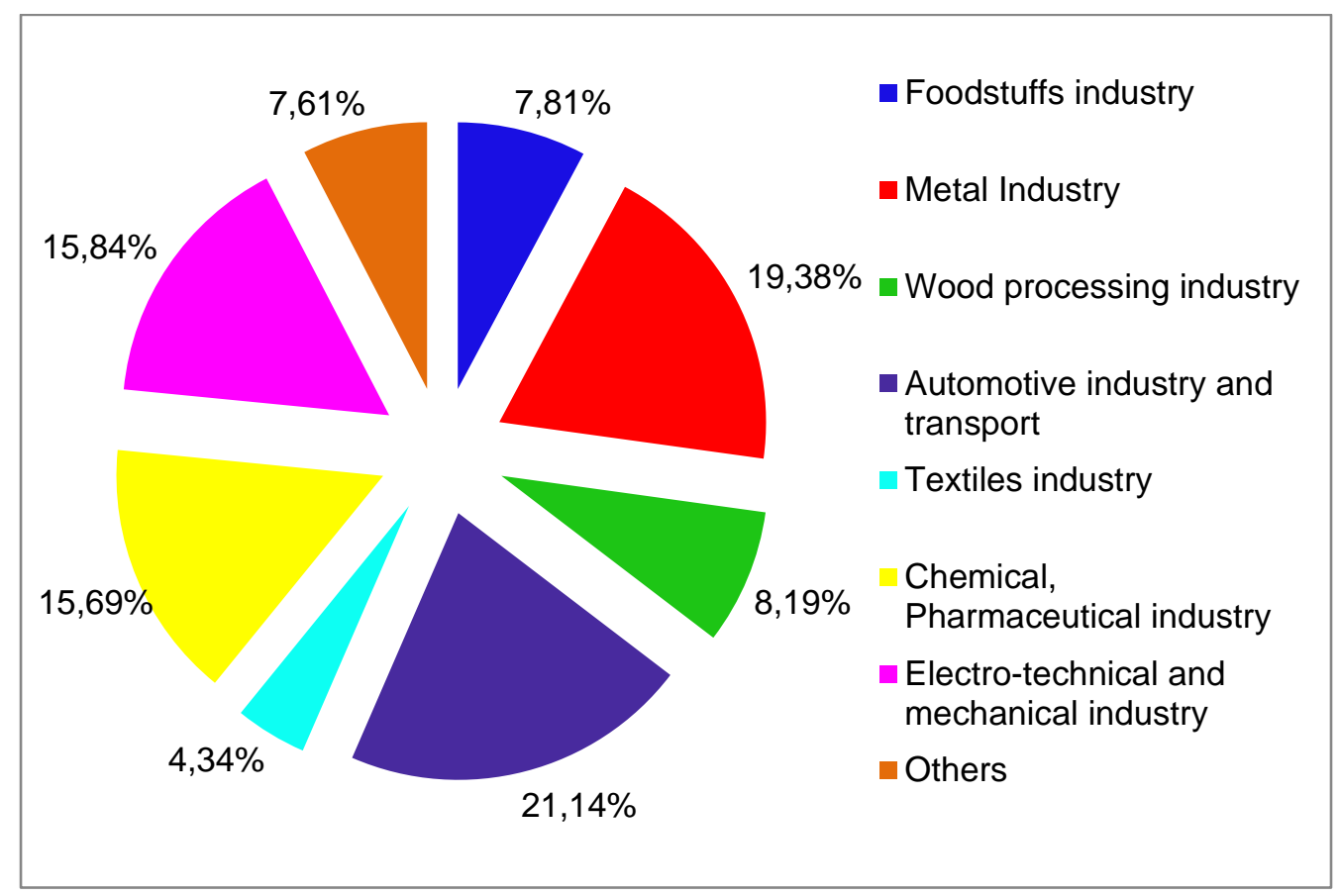

Source: Own adjustment based on data - Slovakia, avalaible: <http://ec.europa.eu/ enterprise/policies/industrial-competitiveness/monitoring-member-states/index_en.htm>

Figure 1 shows the manufacturing industry (GDP at basic prices). The largest share of GDP in Slovakia is the automotive industry. The growth of total production in Slovakia involved in manufacture of machinery and equipment $56.5 \%$ and manufacture of transport equipment $47 \%$.

In 2013, Slovakia produced 980,000 cars together, Kia Motors Zilina 339,000 cars, Volkswagen Bratislava 345,540 cars and Peugeot Citroen Trnava 315,050 vehicles. The automotive industry in Slovakia employs over 80,000 workers.

Among the biggest exporters include Samsung Electronics Europe Logistics B.V. Volkswagen Slovakia SpA, PCA Slovakia, KIA Motors Slovakia Ltd., U.S. Steel Kosice, Sony Slovakia Ltd., Slovnaft SpA, Mondi SCP SpA, Canon Europe N.V. Tatravagonka SpA (CzechTrade, 2016)

Table 1. Macroeconomic indicators of SR

\begin{tabular}{|l|c|c|c|c|c|c|c|}
\hline & 2010 & 2011 & 2012 & 2013 & 2014 & 2015 & 2016 \\
\hline Unemloyment rate & $14,40 \%$ & $13,59 \%$ & $14,44 \%$ & $13,50 \%$ & $12,29 \%$ & 11,50 & 9,70 \\
\hline Inflation & $1 \%$ & $4,10 \%$ & $3,60 \%$ & $1,40 \%$ & $-0,10 \%$ & 1,00 & 0,70 \\
\hline GDP & $4,40 \%$ & $3,00 \%$ & $1,80 \%$ & $0,90 \%$ & $2,90 \%$ & 2,80 & 3,40 \\
\hline
\end{tabular}

Source: Own adjustment based on data Central Office LSAF (2016) 
In the table 1 we can see the evolution of unemployment, inflation and GDP in the Slovak Republic. The unemployment rate in 2013 reached $13.5 \%$, compared with the EU countries remained above average. Long-term unemployment problem still persists when three unemployed roughly two were out of work for more than one year. Unemployment among member states in Slovakia relatively high. Since 2012, continues a gradual reduction of unemployment and the prospects for the future have a positive trend.

\section{Comparison of the structure of industry in some countries}

For comparison, we chose from the statistics the structure of industry in Slovakia, the Czech Republic, Hungary, Poland, Denmark and the Netherlands. The industrial structure in these countries is formed by the food industry and tobacco, metalworking industry, wood processing, automotive and transport, clothing industry, the chemical and pharmaceutical industry, electrical and engineering industries, other industries.

Figure 2. Comparison of industrial structure of selected EU countries

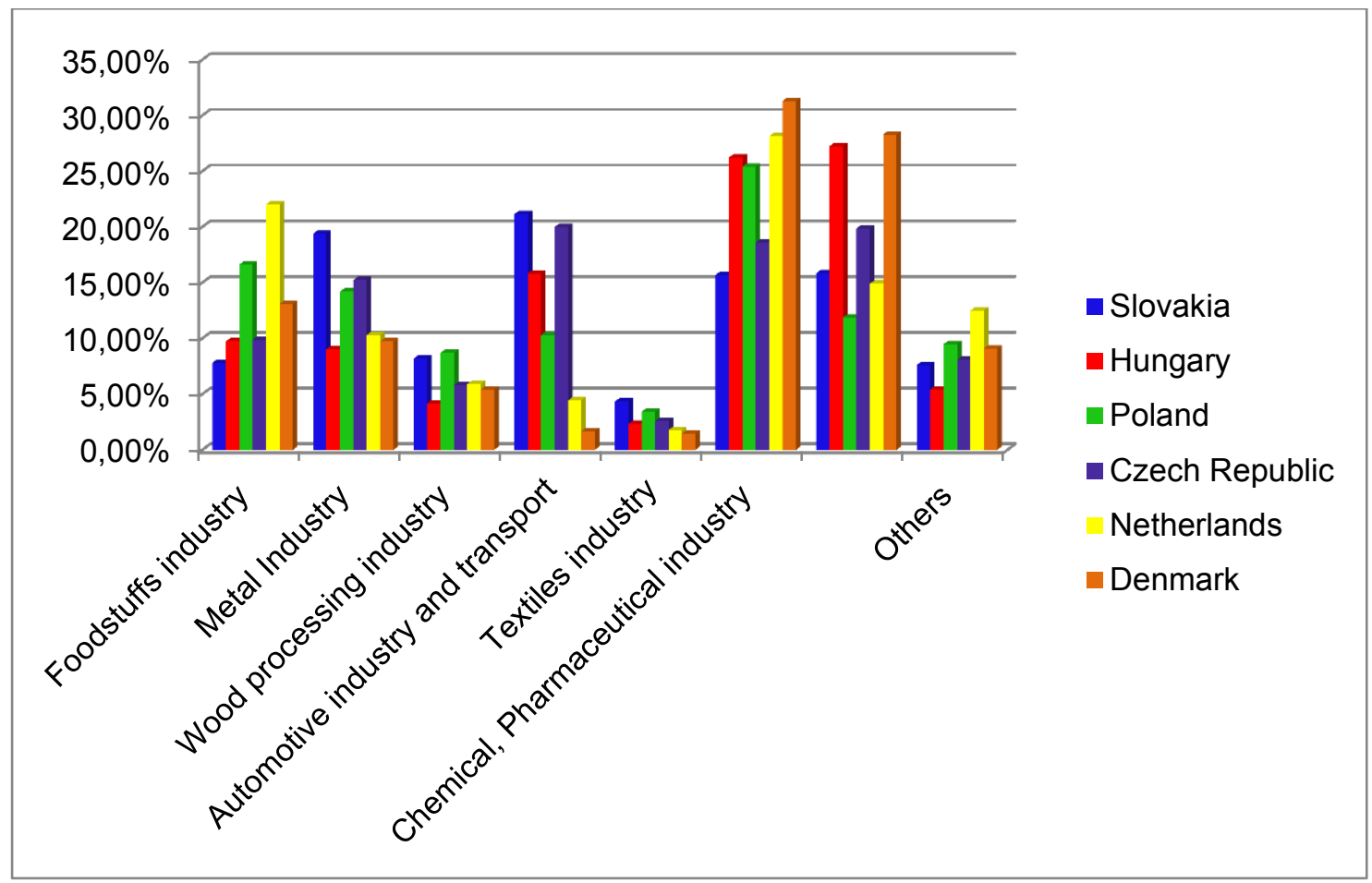

Source: Own adjustment based on data EC.

In Fig. 2 we can see the composition of the industrial structures of selected countries. The Slovak Republic has the most developed automobile industry among the selected EU countries. It also leads in the metal industry. Least-developed automotive industry is Denmark. Clothing is not widely developed in either of the compared countries. Food, beverage and tobacco industries are among the most developed in Denmark. We can say that the V4 countries are much more focused on the industry than developed countries Denmark and the Netherlands. 


\section{Discusion}

Slovak Republic has the most developed automobile industry. This is due to three car companies established in Slovakia. Industrial policy of the Slovak Republic must be formulated so that at the same time creating conditions for increasing the competitiveness of the industry while supporting sustainable development. It is necessary for the government to ensure the competitiveness bear in mind the increasing employment, improving quality of life and reducing environmental pollution. It is therefore necessary to implement measures such as increasing employment throughout Slovakia, as can be seen striking differences in unemployment rates by region. (Soltes, 2016)

It is necessary to adapt the education to market requirements and pay attention to cooperation between universities, public institutions and the private sector. To increase competitiveness, it is necessary creation a supportive business environment, such as improving the tax system, labour - legal legislation, elimination of corruption, etc.

To ensure the attractiveness of the country it is necessary to build infrastructure also create some applied research and innovation centres. The future is in technology and it is important the construction of science parks. Industry is one of the biggest enemies of the environment, hence the need for support material and less energy-intensive production, boost industrial development that does not endanger development opportunities of future generations.

\section{Conclusion}

Industrial policy should aim to ensure a higher quality of life for residents and increase the country's competitiveness. Industrial policy should be formulated so as to create conditions for increasing the competitiveness of the industry while supporting sustainable development. Sustainable development includes three aspects economic, social and environmental. All three aspects of sustainable development must be equally taken into account. In the case of industrial policy it is therefore to promote a form of industrial development that does not endanger development opportunities of future generations.

Acknowledgment: This contribution was undertaken as a part of the research projects VEGA 0733/15, VEGA 1/0693/16

\section{References}

Business Alliance of Slovakia - BAS (2015). The Global Competitiveness Index 2014-2015 Rankings. Avaliable: < http://alianciapas.sk/wp-content/uploads/2014/09/GCR_Rankings_2014-2015.pdf>.

Central Office of Labour, Social Affairs and Family (2016). Statistics. Avaliable: www.upsvar.sk/ statistiky/nezamestnanost-mesacne-statistiky.html?pageid $=1254$

CzechTrade (2016). Slovakia: Trade and economic cooperation with the Czech Republic [Slovensko: Obchodní a ekonomická spolupráce s ČR]. Avaliable: <http://www.businessinfo.cz/cs/clanky/ slovensko-ekonomicka-charakteristika-zeme-17586.html\#sec3>. 
DANESHJO, N. et al. (2016). Marketing and management information system and research system. FedEX Office Print \& Ship Center : San Antonio, $288 \mathrm{p}$.

European Commission (2014). Industrial competitiveness: Commission reports underline need for incisive action by EU and Member States. Avaliable: http://europa.eu/rapid/press-release_IP-14989 en.htm

European Commission (2016). EU Industrial Policy. Avaliable: https://europa.eu/ europeanunion/documents-publications/statistics_en

European Parliament (2016). General principles of EU industrial policy. Avalaible: http://www.europarl.europa.eu/atyourservice/en/displayFtu.html?ftuld =FTU_5.9.1.html

LIPKOVA, L. et. al. (2011). European Union [Európska Únia]. Bratislava: Sprint, 446 p.

NEMCOVA, E. (1998). Industrial policy in the European Union [Priemyselná politika v krajinách Európskej únie]. Prognostický ústav SAV, $131 \mathrm{p}$.

NEMCOVA, E. et al. (2013). Structural adjustment of small and open economy [Štrukturálna adaptácia malej a otvorenej ekonomiky]. Bratislava: Ekonóm, 165 p.

PORTER, M. E. (1990). The Competitive Advantage of Nations. New York : Free Press Edition.

SIPKO, S. (2004). Industrial policy [Priemyselná politika]. Úrad vlády Slovenskej republiky. Bratislava

SOLTES, V., REPKOVA STOFKOVA, K. (2016). The impact of business environment on regional disparities.In: Innovations in science and education. Prague, Central Bohemia University, pp. 187-191.

STOFKOVA, K. (2013). Business network [Siet'ové podnikanie]. In: Manažment a siet'ové podnikanie vo vedomostnej ekonomike. Žilina: Žilinská univerzita, pp. 25-60.

VIDOVA, J. (2015) Industry and new industrial policy [Priemysel a nová priemyselná politika] Avaliable: <http://www.derivat.sk/files/2014\%20financne \%20trhy/2014_Jan_Vidova_priemysel.pdf>. 